\title{
Geskiedenis en gesigshoek met besondere verwysing na die rol van die profete in Kronieke
}

\author{
H.F. van Rooy \\ Departement Klassieke en Semitistiek \\ Potchefstroomse Universiteit vir $\mathrm{CHO}$ \\ POTCHEFSTROOM
}

\begin{abstract}
The writing of history can not be separated from the point of view of the historian. Objective historiography, therefore, remains an illusion. This problem is examined in this paper, with the treatment of prophets in (hronicles as an example. In the discussion of the role of prophets in ('hronicles, attention is given to the prophets mentioned in regnal résumés and in sections with and without parallels in the Deuteronomistic History. In Chronicles the new' view of the roles of prophets is demonstrated. The point of view of the writer(s) of Chronicles in the Persian period must be kept in mind to understand the book's message, because this point of view" has resulted in a different perception of the role of the prophets than that of the Deuteronomistic History. Chronicles contains a new message in a new time pointing to a new way into the firture. The importance of point of view for the writing of history is also demonstrated by way of a discussion of one episode in South African church history.
\end{abstract}

\section{Inleiding}

Kan die beskrywing van geskiedenis - gewone geskiedenis, kerkgeskiedenis of geskiedenis soos beskryf in die Bybel - werklik objektief wees? Ińdien die beskrywing van geskiedenis nie objektief kan wees nie, beteken dit dan dat so ' $n$ beskrywing altyd subjektief en relatief moet wees? In hierdie artikel gaan aan hierdie vrae aandag gegee word, met as voorbeeld vir die bespreking die wyse waarop profete in die boek Kronieke aan die orde gestel word. Die voorbeeld word voorafgegaan deur 'n bespreking van die verband tussen geskiedenis en die gesigshoek van die geskiedskrywer. Met geskiedenis word bedoel die beskrywing van die geskiedenis en nie die gebeure in die verlede as sodanig nie. Die verband tussen die gesigshoek van die geskiedskrywer en sy beskrywing van die geskiedenis moet steeds raakgesien en in gedagte gehou word wanneer die geskiedenis van die kerk vandag beskryf word. 
In die bespreking van die hantering van profete in Kronieke sal aandag gegee word aan die wyse waarop profete gehanteer word in die opsommings van die regeringstye van konings, in parallelle gedeeltes in die Deuteronomistiese Geskiedwerk en in gedeeltes waar daar nie parallelle is in die Deuteronomistiese Geskiedwerk nie. Ook sal aandag gegee word aan die gevalle waar profete in die Deuteronomistiese Geskiedwerk nie parallelle in Kronieke het nie. Daarna sal die veranderde siening van profete in Kronieke aan die orde kom

\section{Geskiedenis en gesigshoek}

Objektiewe geskiedskrywing is 'n ideaal wat veral uit positiwistiese hoek nagejaag is, omdat sodanige geskiedskrywing ten minste 'n waardevrye ondersoek impliseer (Rienstra, 1984:69). lets van hierdie doelstelling word gereflekteer in Christina Landman se beoordeling van Suid-Afrikaanse kerkgeskiedskrywung. In haar beoordeling van kerkgeskiedskrywing in Suid-Afrika tot op datum oordeel sy dat daar twee vorme van kerkgeskiedskrywing in Suid-Afrika geidentifiseer kan word, naamlik 'n pre-kritiese en 'n post-kritiese benadering. Vir haar is ' $n$ kritiese benadering (wat dan eintlik 'n derde benadering is) gewens ondat dit gepaard gaan met die objektiewe seleksie van bronne, die onbevooroordeelde lees van die bronne en die skryf van kerkgeskiedenis sonder "commitment to one's position in the political and socio-economic order" (Landman, 1988:68-69). Hierteenoor kan gevra word of ' $n$ mens jou werklik van jou staanplek in die wêreld kan losmaak.

Enige beskrywing van geskiedenis word steeds uit 'n sekere hoek gedoen: dit het Popper ons geleer. Wat in die verlede gebeur het, is beskryf en geinterpreteer vanuit ' $n$ bepaalde raamwerk. Volgens Popper (1962:265) bevat die bronne wat historici so graag vir hulle geskiedskrywing gebruik, ook maar 'n seleksie van materiaal sodat geskiedskrywing in alle geval interpretasie is. Interpretasie, aldus Popper (1962:266), verteenwoordig 'n spesifieke gesigshoek, gevolglik kan geen interpretasie ooit as finaal beskou word nie (vgl. Popper, 1962:268). Elke interpretasie probeer 'n antwoord gee op die vraag hoe huidige probleme met die verlede verband hou en hoe gevorder kan word na 'n oplossing (Popper, 1962:268). Ons gee self betekenis aan die geskiedenis (Popper, 1962:278). In aansluiting hierby noem Van den Bergh (1977:1) die historikus die skepper van die geskiedenis. Die geskiedbeskouing bly relatief en die historikus is steeds subjektief teenwoordig in sy werk (Van den Bergh, 1977:4). 'n Voorbeeld hiervan is die verskillende visies op die verkiesing van 1948. Vir Afrikaners was dit 'n groot waterskeiding, vir Engelse historici 'n groot ramp en vir swart historici 'n katastrofe (Van Jaarsveld, 1989:34).

Van Jaarsveld (1984:6-7) bied ' $n$ voorbeeld van groter omvang in sy bespreking van vier tendense wat hy in die Suid-Afrikaanse historiografie onderskei. In elk- 
een van die benaderings word daar na 'n sondebok vir die probleme van die land gesoek. In die tradisionele, konserwatiewe benadering word op die blanke koloniste en republikeine gekonsentreer, met die progressief-imperialistiese benadering van Groot-Brittanje as die sondebok. Vir die meer liberale Engelse historiografie na die Eerste Wêreldoorlog was die kleurvraagstuk 'n besondere verwysingspunt, met die Afrikaners as die sondebokke. Na die Tweede Wêreldoorlog het ' $n$ meer radikale benadering na vore gekom, met klas as 'n belangrike verwysingspunt in 'n Marxistiese benadering: Britse imperialisme en kapitalisme is as die sondebokke uitgesonder. Na 1948 het 'n swart radikale benadering na vore gekom. Hierin is vir die eerste keer behoorlike aandag gegee aan die rol van die swart bevolking van Suid-Afrika. Die geskiedenis is herskryf in terme van verowering, onderwerping, weerstand en bevryding - 'n benaderinswyse met die implikasie dat die blankes vir hierdie negatiewe erflating van die geskiedenis verantwoordelik is. Hieruit is duidelik dat die historikus nie te bevry is van sy eie historiese konteks nie (vgl. Rienstra, 1984:74).

Nie net die historikus nie, maar ook die kerkhistorikus werk met gesigshoeke, byvoorbeeld 'n konfessionele gesigshoek (vgl. Van der Watt, 1975:13). Die kerkgeskiedenis is nie maar net besig om te beskryf nie, maar ook om te kyk na die kragte en oortuiginge agter die verskynsels, gebeurtenisse en toestande (Van der Watt, 1975:5). Brown (1988) gee 'n oorsig oor die ontwikkeling van die kerkgeskiedenis. Geskiedenis en kerkgeskiedenis word volgens hom bestudeer en beskryf, nie om God te vind nie, maar om iets te verstaan van sy weg met ons en sy wêreld (Brown, 1988:43).

In die beskrywing van geskiedenis moet die historikus getrou bly aan die getuienis oor die verlede, maar sonder om te verval in die gevaar van die 'foundationalisme', waarin die onfeilbaarheid en onveranderlikheid van God en sy Woord verwar word met die mens se feilbare en veranderlike verstaan van die Woord (Rienstra, 1984:77, 81).

In hierdie artikel gaan die saak valn geskiedskrywing en gesigshoek toegelig word aan die hand van ' $n$ voorbeeld uit Kronieke. Die doel van die geskiedskrywing van Kronieke kan ook vergelyk word met die opmerking van Brown waarna hierbo verwys is. Die Bybelse (geskied)skrywer(s) wou die lesers ook iets leer van God se weg met hulle deur die verlede om daana 'n weg vorentoe aan te dui.

Die geskiedskrywers in die Ou Testament het op 'n sekere wyse dieselfde gedoen as moderne geskiedskrywers: hulle het ook probeer on soveel as moontlik oor die verlede uit te vind en dan gepoog on sin daarin te vind (Licht, 1984:108). Die sin het hulle daarin gevind dat God 'n langtennynplan met sy volk gehad het, naamlik om hulle te vestig en te bewaar (Licht, 1984:11, 115). Ook vir die geskiedskrywers van die Ou Testament was daar die normale drie stappe nodig, naamlik die identifisering van getuienis, die interpretasie daarvan en die samestel- 
ling van 'n rekonstruksie van die gebeure (Halpern, 1988:6). 'n Geskiedwerk probeer altyd om te kommunikeer oor gebeure buite die teks (Halpern, 1988:II). Halpern en Licht oordeel meer positief oor die historiese waarde van die OuTestamentiese historiese boeke as byvoorbeeld Miller en Hayes. Miller en Hayes (1986:78) is oortuig daarvan dat die basiese gang van die verhaal in GenesisJosua 'n kunsmatige en teologies bepaalde literêre konstruksie is. Hulle hou nie genoeg rekening daarmee dat die historiese werke in die $\mathrm{Ou}$ Testament geskiedenis wou beskryf nie, al is dit dan met die beperking van min bronne en die lang tyd wat verloop het tussen die gebeure self en die uiteindelike beskrywing daarvan. Deist (1986:100) wys daarop dat die Ou-Testamentiese vertellings vr die eerste hoorders daarvan die enigste geskiedenis was wat hulle geken het. Die verhale was gerig op die eerste hoorders/lesers. Deist onderskei vier moontlikhede oor die wyse waarop die verhale die hoorders kon aanspreek (1986:100102): die verhale kon die hoorders inlei in die tradisies van hul volk en luulle so onderrig. Ook kon die verhale die legitimiteit van bestaande praktyke aandui, bestaande praktyke kritiseer of vernuwend daarop inwerk.

\section{Profete in Kronieke}

By die bestudering van die wyse waarop profete in die boeke 1 en 2 Kronieke aan die orde kom, moet onthou word dat die boeke self geskryf is lank na die gebeure wat daarin beskryf word. Deur hierdie boeke wou die skrywer(s) die geskiedenis herinterpreteer vir hulle eie tyd. Om te aanvaar dat die boek iets reflekteer van die veranderende omstandighede waartydens dit geskryf is, is natuurlik ' $n$ baie komplekse aangeleentheid met baie probleme (vgl. Carroll, 1989:204-206). Hierdie boeke gee voor om die geskiedenis van Israel te verhaal, met toespitsing op Dawid, Salomo en die koninkryk van Juda. Die vraag ontstaan dus wat 'n mens uit 'n teks soos Kronieke kan aflei van die tyd waaroor en die tyd waarvoor dit geskryf is. Dat daar van bronne gebruik gemaak is in die samestelling van die teks is duidelik, veral by die vergelyking van Kronieke met Samuel-Konings. Miller en Hayes (1986:156) oordeel dat Kronieke Samuel en Konings in basies die huidige vorm gebruik het, en dat dié twee boeke veral toegespits is op kultiese en religieuse sake. Op grond van hierdie toespitsing word gevolglik baie aandag gegee aan die tempel in Jerusalem en die inrigting daarvan. Dat Kronieke 'n tendensieuse geskrif is, blyk vir hulle uit onder andere die hantering van Dawid, die groot held van die skrywer(s) van Kronieke (Miller \& Hayes, 1986:157).

In die geskiedenis van Israel het sekere dinge gebeur. In sowel die Deuteronomistiese Geskiedwerk (Josua-Konings) as in Kronieke word pogings aangewend om die geskiedenis te beskryf. Elkeen van die beskrywings is in 'n sekere tyd vir 'n sekere adres geskryf. In die teks word die geskiedenis van die volk herskep om 'n nuwe boodskap in 'n nuwe tyd te bring. Deur die twee tekste oor die geskiedenis van Israel te vergelyk, word die boodskap van elk in sy eie tyd 
duideliker. Die reînterpretasie van Kronieke hou verband met die ontstaanstyd van die boeke, al kan ons steeds net deur die oë van die skrywer(s) daarna kyk (vgl. Long, 1977:5). Die ontstaantyd van Kronieke was in die Persiese periode, 'n tyd waarin die volk nie meer polities afhanklik was nie, maar 'n tydperk waarin Juda 'n onderdeel was van die groot Persiese Ryk. Die volk was slegs godsdienstig 'n eenheid en in die godsdienstige eenheid was die plek van die tempel en die kultus baie belangrik.

In paragrawe 3.1 tot 3.5 sal daar verder aandag gegee word aan die voorkoms, woorde en dade van profete in Kronieke, ook in vergelyking met die Deuteronomistiese Geskiedwerk. Daar is 'n aantal studies wat volledig aandag gee aan die profete in die twee boeke (vgl. Micheel, 1983 en Petersen, 1977). In genoemde onderafdeling sal gekonsentreer word op die boodskap wat die profete gehad het vir die tyd waarin die boeke geskryf is, om sodoende iets van die gesigshoek van die skrywer(s) duidelik te maak. Die gesigshoek reflekteer 'n tyd toe die klassieke profetisme in 'n verwante maar verskillende verskynsel verander het (Petersen, 1977:6). Die wyse waarop profete in Kronieke beskryf word, sal slegs aan die hand van 'n aantal verteenwoordigende voorbeelde bespreek word.

\subsection{Profete in opsommings van regeringstye van konings}

Aan die begin of aan die einde van die bespreking van ' $n$ koning se regering word daar telkens opsommings van die koning se lewe en werk gegee (vgl. De Vries, 1989:434). In die slotopsommings word daar dikwels na bronne verwys. In die vyftien gevalle in Kronieke word daar agt keer verwys na werke van profete (1 Kron. 29:29; 2 Kron. 9:29; 12:15; 13:22; 20:34; 26:22; 32:32 en 33:18-19).

Twee voorbeelde is voldoende om die hantering van profete in die opsommings te illustreer. Aan die einde van die tydperk van Dawid staan daar in 1 Kronieke 29:29-30:

En die geskiedenis van koning Dawid, die vroeëre en die latere, kyk, dit is beskrywe in die Geskiedenis van die siener Samuel en in die Geskiedenis van die profeet Natan en in die Geskiedenis van die siener Gad, saam met sy hele koningskap en sy heldedade en die tye wat oor horn en oor Israel en oor al die koninkryke van die lande heengegaan het (1933/53-vertaling).

Die afsluiting van die beskrywing van die tyd van Josafat word soos volg verwoord (2 Kron. 20:34):

En die verdere geskiedenis van Josafat, die vroeëre en die latere, kyk. dit is beskrywe in die Geskiedenis van Jehu, die seun van Hanani, wat opgeneem is in die Boek van die konings van Israel (1933/53-vertaling). 
Die volgende profete word só in Kronieke vermeld: Samuel, Natan, Gad, Ahía, Iddo, Semája, Jehu, Jesaja en Hosai. Dit is 'n vraag of die werke waana verwys word, aparte werke was. Die standpunt dat daar wel sulke werke was, word deur Micheel (1983:79) verwerp. Dit is ook moontlik dat hierdie verwysings op die Deuteronomistiese Geskiedwerk wys, al word al die profete nie daarin aangetref nie (vgl. De Vries, 1989:109-110; Dillard, 1987:74). Auld (1983:17) dink dat die opsommings in Konings en Kronieke kruisverwysings tussen die twee werke is op plekke waar albei verskil van 'n gemeenskaplike bron. Wat in elk geval duidelik is, is dat die skrywer(s) deur die verwysings na profete homself/hulleself in die profetiese tradisie wil plaas.

\subsection{Profete in Kronieke met parallelle in die Deuteronomistiese Geskiedwerk}

Daar is ' $n$ aantal gevalle waar profete in Kronieke voorkom met parallelle in die Deuteronomistiese Geskiedwerk. Al die gevalle word deur Micheel (1983:11-38) bespreek. Enkele voorbeelde kan aangehaal word on die wyse waarop die twee werke ooreenstemmende gedeeltes hanteer, te verduidelik.

1 Kronieke 17 kan met 2 Samuel 7 vergelyk word - twee gedeeltes waarin Dawid se begeerte on 'n tempel te bou, behandel word. In hierdie geval is daar slegs enkele klein verskille, soos byvoorbeeld die weglating van 2 Samuel 7:14 met die verwysing na die inoontlike oordeel oor Salomo (vgl. De Vries, 1989:153). Hierdie verwysing kom ook in die Septuagint voor, sodat die verskil nie te wyte kan wees aan 'n ander Vorlage van Samuel as die Masoretiese teks nie. In sommige gevalle kan die konteks waarbinne 'n episode in die twee tekste geplaas word, verskil. So is 2 Samuel 24 deel van die aanhangsel tot 2 Samuel (ook in die Septuagint), terwyl die verhaal daarin vervat, in Kronieke deel is van die basiese verhaal (vgl. Ackroyd, 1973:73). Die konteks van die verhaal van Miga en die valse profete in 2 Kronieke 18 verskil ook van die konteks in Konings. In Konings is dit deel van die geskiedenis van Agab en in Kronieke deel van Josafat se geskiedenis. Dillard (1987:139) sê dat die twee gedeeltes twee preke met dieselfde teks is. Konings wys na die vervulling van die profetiese woord as een van die oorsake van die ballingskap, terwyl Kronieke wil wys op die gevaar van bondgenootskappe met vreemde nasies. Dit blyk dus dat Konings se hantering van die gebeure aansluit by 'n doelstelling van die boek, naamlik om die volk in ballingskap te wys op die redes vir die oordeel wat hulle getref het. In Kronieke hou die boodskap eerder verband met die wyse waarop die volk hulle as God se volk in die tyd na die ballingskap moes suiwer hou in 'n nuwe tyd

Daar kom enkele gevalle voor waar Kronieke verwys na gebeure wat in die Deuteronomistiese Geskiedwerk beskryf word, maar nie in Kronieke self nie. Die verwysing na die profesie van Ahia in 2 Kronieke 10:15 is ' $n$ voorbeeld. Die 
profesie word in 1 Konings 11:29-39 beskryf. Kronieke verwys net na die vervulling van die profesie, sodat veronderstel word dat die oorspronklike leser kennis gedra het van die gedeelte in Konings (Dillard, 1987:87).

\subsection{Profete in Kronieke sonder 'n parallel in die Deuteronomistiese Geskiedwerk}

Kronieke bied soms nuwe materiaal oor profete sonder direkte parallelle in Samuel en Konings. Vir 'n volledige bespreking, vergelyk Micheel (1983:39-70). Sommige van die gevalle hou indirek verband met gegewens in die Deuteronomistiese Geskiedwerk, terwyl sommige gevalle hoegenaaind geen verband het met gegewens in die Deuteronomistiese Geskiedwerk nie.

Voorbeelde sonder enige verband sluit in 'n aantal algemene verwysings na profete, soos in I Kronieke 16:22 (in 'n psalm wat ooreenkom met dele van Psalm 105) en in Josafat se aanmoediging dat die volk in God moet glo (1 Kron. 20:20). Vergelyk ook 2 Kronieke 24:19 en 36:16.

In 1 Kronieke 25:1-3 kom 'n besonderse gebruik van die werkwoord $n b^{\prime}$ voor. Hierdie werkwoord verwys na die Levitiese tempelmusikante: daardeur word profetiese optrede en liturgiese musiek verbind. Vir die kronis gaan hierdie saak terug na Dawid, wat die musikante die opdrag gegee het on met musiekinstrumente te profeteer (vgl. Eaton, 1984:97. Die tempelınusici moes dus deur profetiese inspirasie werk en die komponering en uitvoering van liturgiese musiek is as 'n vorm van profesie beskou (Blenkinsopp, 1984:254). Die verbinding van die Leviete met profetiese handelinge is tipies van die kronis (vgl. Petersen, 1977:62, 66).

Daar kom in Kronieke ook 'n aantal profete voor wat glad nie die Deuteronomistiese Geskiedwerk vermeld word nie, soos Jahásiël in 2 Kronieke 20:14-17. In vers 37 van dieselfde hoofstuk word daar verwys na Eliëser, die seun van Dódawa. In albei gevalle word die vervulling van die profesie teen Josafat in dieselfde hoofstuk beskryf. Verdere verwysings sonder parallelle in die Deuteronomistiese Geskiedwerk is die brief van Elia in 2 Kronieke 21:12-15, Sagäria, die seun van Jójada (2 Kronieke 24:20), 'n ander Sagaria in 2 Kronieke 26:5 en Oded in 2 Kronieke 28:9-11.

Daar kom ook gevalle voor waar die kronis nuwe inateriaal na vore bring oor profete wat wel in ' $n$ ander verband in die Deuteronomistiese Geskiedwerk voorkom. Die brief van Elia is hiervan 'n voorbeeld. Soms word daar in Kronieke net verwys na 'n profeet van wie meer bekend is in die ander geskiedwerk, soos Heman, die siener van die koning, wie se seuns onder die musikante was wat Dawid aangewys het. So word 'n profeet en die Levitiese musikante verbind. Hanson (1975:271-273) toon aan dat Kronieke 'n meer positiewe beeld van die 
Leviete skets as wat gangbaar was in die tyd voordat Kronieke geskryf is. Die bitter stryd wat daar tussen priesterlike groepe was, het tot 'n einde gekom. Die profeet Semaja is nog ' $n$ voorbeeld van 'n profeet waaroor Kronieke nuwe gegewens na vore bring. Hy word vermeld in 2 Kronieke $11: 2-4$, met 'n parallel in Konings. In 2 Kronieke $12: 5$ en 7-8 word hy weer vermeld, maar sonder 'n parallel. Hy het oordeel aangekondig, wat uitgeloop het op bekering en die opskorting van die oordeel. 2 Kronieke 12 kan dalk beskou word as 'n kronistiese interpretasie van l Konings 14:21-31, waarin die profeet se woorde die interpretasie duidelik maak (vgl. Micheel, 1983:41).

Daar is ook gevalle waar Kronieke gegewens uit die Konings-boek uitbrei en in die proses ' $n$ profeet aan die orde stel. Dit is moontlik die geval in 2 Kronieke 15 : 1-8, waar Asarja, die seun van Oded, aan die woord gestel word (vgl. Micheel, 1983:41-45). Hierdie episode mag verband hou met 1 Konings 15:12, waar daar van hervormings van Asa melding gemaak word. In Kronieke word die rol van Asarja in die hervormings aangedui. Soortgelyke voorbeelde word in 2 Kronieke 16:7-10 en 12 aangetref, asook in 2 Kronieke 19:2-3, 25:7-9 en 35:25. Kenmerkend van die nuwe gegewens in Kronieke is dat dit kommentaar lewer op gebeure wat in Konings beskryf word In die kommentaar word gebeure verbind aan die koning se verhouding met die Here sodat duidelik word dat vertroue op God seën bring, maar gebrek aan vertroue oordeel teweegbring (vgl. Micheel, 1983:67-71).

\subsection{Profete in die Deuteronomistiese Geskiedenis met geen parallelle in Kronieke nie}

Daar word ' $n$ hele aantal gevalle aangetref waar profete in Samuel en Konings vermeld word sonder parallelle in Kronieke. Sommige van die gevalle het te doen met die Noordelike Ryk of dele van die geskiedenis wat nie in Kronieke aan die orde kom nie. Wat die profete betref wat in die Noordryk gewerk het, het die volgende nie parallelle in Kronieke nie: die man van God uit Juda en die ou profeet van Betel (1 Konings 13), Elia en Elisa, Jehu (1 Konings 16), die verwysing na die 100 profete wat deur Obadja weggesteek is ( 1 Konings 18.4), die profete wat teen Agab geprofeteer het (1 Konings 20), die profeteseuns (2 Konings 2-5 en 9), Jona ( 2 Konings 14:25) en die deuteronomistiese beoordeling van die val van Samaria (2 Konings 17), met die verwysing na profete in verse 13 en 23. Natan kom meer kere in die Deuteronomistiese Geskiedwerk voor en slegs een keer in Kronieke, parallel aan 2 Samuel 7. Aan die ander kant verwys 2 Kronieke 9:29 weer na 'n werk van Natan as een van die bronne vir die tyd van Salomo, wat waarskynlik kennis van 1 Konings 1 veronderstel (Micheel, 1983: 12). Die verswyging van sommige van die profete mag bloot daarnee verband hou dat hulle noordelike profete was, maar tog word sommige noordelike profete wel gebruik (Begg, 1988a:8). Sommige van die gevalle mag egter eerder verband 
hou met die skrywer(s) se gesigshoek. Begg (1988a:10-11) is byvoorbeeld van mening dat die verswyging van Elisa verband mag hou met die gebeure in 2 Konings 3, waar Elisa aangekondig het dat die bondgenootskap van Josafat, Joram en 'n koning van Edom 'n oorwinning sal behaal onder die seën van die Here. Dit is nie in ooreenstemming met die skrywer(s) se duidelike standpunt teen bondgenootskappe met die vreemde nasies nie. Wat Esegiël betref, kan die feit dat hy weggelaat word in Kronieke dalk ook verband hou met die gesigshoek van die skrywer(s) van Kronieke. Esegiël stel die Leviete ondergeskik aan die Sadokitiese priesters terwyl die skrywer(s) van Kronieke die rol van die Leviete juis wil beklemtoon (vgl. Begg, 1986:342-343). Esegiël se beskrywing van die dwaling van die Leviete teenoor die getrouheid van die Sadokiete in Esegiël 44:10 en 15 kon ook daartoe bygedra het dat Esegiël verswyg is in Kronieke.

Die feit dat die klassieke profete min aandag in Kronieke kry, is 'n saak waaraan Begg (1988b) besondere aandag gegee het. Jesaja se rol word byvoorbeeld onderbeklemtoon ten koste van Hiskia. Die onderbeklemtoning hou verband met die besondere plek wat Hiskia in Kronieke ontvang het. Hy het self die inisiatief geneem vir sy hervormings en hy word feitlik as 'n profetiese figuur geskets. Begg (1988b:102) stel dat Hiskia beskou kan word as die profeet van sy tyd. Jeremia het wel 'n belangriker rol te speel in Kronieke, maar hy word op dieselfde manier as Jesaja gehanteer (Begg, 1988b:103).

\subsection{Die veranderde siening van profete in Kronieke}

Begg (1988b:100-101) onderskei vier algemene tendense waarvolgens Kronieke die profete hanteer:

* Kronieke gaan heelwat verder as die Deuteronomistiese Geskiedwerk om die profetiese dimensie van Israel se geskiedenis te beklemtoon en bring nuwe inligting na vore.

* Profetiese toesprake in Kronieke is meer verwant aan die profetiese boeke.

* Die profete in Kronieke stem meer ooreen met die klassieke profete as met die deuteronomistiese profete.

* Kronieke gebruik profete om gapings in die deuteronomistiese opeenvolging van profete in die Suide te vul.

In die onderhawige artikel gaan daar ondersoek ingestel word na die verandering in die interpretasie van die funksie van profete en wat hierdie veranderde interpretasie reflekteer ten opsigte van die tyd van Kronieke self. Volgens Wilson (1980:292) het die profete 'n baie belangrike rol vervul in die skrywer(s) se siening van die samelewing. Die opkoms van die profetisme het saamgeval met die ontstaan van die monargie (Wilson, 1980:293). Dat die wyse waarop profete be- 
skou is, met verloop van tyd verander het, is duidelik aangetoon deur Auld (1983).

Die baie verwysings na profete in die opsommings van regeringstye is ' $n$ poging van die skrywer(s) om sy/hulle werk aan die profetiese tradisie te verbind. Blenkinsopp (1984:22) oordeel dat die baie sieners en profete wat in Kronieke se bronne vermeld word, aantoon dat profete in die tyd van Kronieke as geskiedskrywers beskou is - die benaming 'vroeère profete' vir die boeke van Josua tot Konings kan hiervan afgelei wees. Kronieke maak van profete historici (Blenkinsopp, 1984:255). Die skrywer(s) van Kronieke was waarskynlik aan die kultus verbonde. Die feit dat die aanvalle van die klassieke profete op die kultus nie in die boeke gereflekteer word nie, kan moontlik gewyt word aan 'n poging om kontinuiteit tussen die profete uit die geskiedenis en die tradisie waaruit Kronieke gekom het, aan te dui.

In Kronieke is die profete sterk aan die konings van Juda verbind. Vir feitlik elke koning was daar 'n profeet wat hom moes aanmoedig of vermaan. Sommige van hierdie profete se beskrywings is uit Samuel en Konings oorgeneem of aangepas. Waar die bron nie sulke profete gehad het nie, het die skrywer(s) nuwe profete na vore gebring. So is profete in Kronieke verbind aan die voortgang van die teokrasie. Hierdie profete het 'n belangrike rol gespeel in die ontstaan van die monargie (Petersen, 1977:55). Hulle het konings vermaan en oordeel of heil aangekondig, afhangende van die koning se reaksie. Wanneer hulle woorde verwerp is, het oordeel gevolg, soos afgelei kan word uit 2 Kronieke 36:16 waar daar staan dat die volk met die profete gespot het. Die optrede van profete word dikwels verbind aan die vergeldingsleer wat in Kronieke voorkom: ongehoorsaamheid bring oordeel en gehoorsaamheid seen. Die verwerping van verdrae met vreemde volke het hierin ook 'n belangrike rol gespeel. 'n Koning se regeringstyd in Kronieke word meermale in duidelik onderskeibare fases ingedeel. Aan die begin van sy regeringstyd was die koning byvoorbeeld gehoorsaam, met seên as gevolg. Na 'n tyd het hy egter gesondig en so onder die oordeel gekom. In Kronieke kom daar dikwels in die tydperk ná die sonde en vóór die oordeel 'n profeet na vore om die oordeel aan te kondig (McKenzie, 1985:114). 'n Tipiese voorbeeld van hierdie skematisering word in 2 Kronieke 25 aangetref. Hierdie hoofstuk handel oor gebeure gedurende die regeringstyd van Amasia. Twee profete wat nie in die parallelle gedeelte in 2 Konings 14 genoem word nie, word vermeld. Eers word gewys hoe gehoorsaamheid seen tot gevolg het (vers 7-9) en daarna hoe ongehoorsaamheid oordeel tot gevolg het (vers 15-16). Positiewe en negatiewe vergelding word verduidelik deur twee onbekende profete aan die woord te stel. In die teokrasie het profete die taak gehad om God se woorde aan die konings van Juda te verkondig en hulle reaksie daarop het seen of oordeel tot gevolg gehad (Dillard, 1987:301). Die lot van die volk en die koning het dus dikwels afgehang van hulle reaksie op die profetiese woord (Eskenazi, 1986:52). 
In Kronieke word daar ook dikwels gepoog om Leviete en profete te verbind. Soms word dit gedoen bloot deur'n geringe opmerking in die gang van die verhaal. 2 Kronieke 35:18 is 'n voorbeeld hiervan, waar daar oor die Paasfees in die tyd van Josia gesê word dat daar nie so 'n Paasfees gevier is sedert die tyd van die profeet Samuel nie (vgl. Wilson, 1980:293). Konings verwys na die tyd van die rigters. Daar word ook soms meer eksplisiete verbande tussen profete en die Leviete gelê, soos in l Kronieke 25:1-3, waarna reeds verwys is. Sommige van die profete is ook Leviete, soos Samuel en Jagasiël (2 Kronieke 20:14-17) en Heman (1 Kronieke 25:4-6). In 1 Kronieke 26:26 word Samuel aan die diens van die Leviete verbind wanneer verwys word na instrumente wat hy geheilig het en wat deur die Leviete bewaar is. In die kultiese diens het profetiese en poëtiese inspirasie oorvleuel (Blenkinsopp, 1984:254). Die Leviete het al hoe belangriker geword in die hiërargie van die tweede tempel en die band tussen die profete en Leviete het hulle posisie in die nuwe gemeenskap gelegitimeer. In 2 Kronieke 20: 13-23 word daar ook 'n tipiese profetiese uitspraak deur 'n Leviet gelewer, wat weer ' $n$ boodskap in ' $n$ later tyd kan bring dat Leviete profetiese take oorgeneem het (Dillard, 1987:157, vgl. ook Petersen, 1977:76-77). Hierdie verbinding van Leviete en profete kan ' $n$ voorbeeld wees van die tempelparty se siening van profesie in hulle tyd (vgl. Petersen, 1977:77). Daar is meer gevalle waar die skrywer(s) die Leviete van hulle tyd verbind aan die profete van die volk se geskiedenis. Kronieke toon aan dat die Leviete agting vir die profesie gehad het en daarom profetiese woorde bewaar het (Sinith, 1971:168). In 2 Kronieke 34:30 word Leviete vermeld onder diegene wat Josia se voorlesing uit die wetboek aangehoor het, terwyl 2 Konings 23:3 na profete verwys. Deur hierdie soort verwysing ontvang die Leviete profetiese sanksie. In Hiskia se reorganisasie is hierdie verbinding baie duidelik. In 2 Kronieke 29:25 word die reorganisasie eksplisiet verbind aan opdragte van Natan en Gad in die tyd van Dawid. In vers 30 word die Leviete beveel om die Here te loof met die woorde van Dawid en van die siener Asaf. In hierdie verbinding word iets gereflekteer van die verdwyning van profesie in die tyd van die skrywer(s) en die opkoms van die Leviete en die Levitiese musikante (Dillard, 1987:236). Die Levitiese musikante ontvang sodoende Dawidiese gesag vir hulle profetiese aktiwiteite (Petersen, 1977:84). lets soortgelyks gebeur in die tyd van Josia in 2 Konings 35:15 (Dillard, 1987: 291). Die Leviete het waarskynlik gepoog on profesie deel van hulle liturgiese opdrag te maak (Smith, 1971:168)

In Kronieke lê die profete ook besondere kleın op die regte kultus (Newsome, 1975:213). 'n Deel van die boodskap is dat Juda se voorspoed onder andere afhang van kultiese getrouheid. Hierteenoor kom baie negatiewe opmerkings van die klassieke profete teenoor die kultus voor. Die profete was selfs verantwoordelik vir die herbou van die tempel (Petersen, 1977:56). Ook die konings het kultiese take in Kronieke verrig. Hiskia is hiervan 'n goeie voorbeeld (Begg, 1988b:102-103) terwyl Dawid en Salomo verdere voorbeelde is (vgl. Newsome, 
1975:204). Die probleem van onvervulde profetiese uitsprake word ook in Kronieke vermy. Die voorspellings wat profete wel mak, slaan op die nabye toekoms en die vervulling van voorspellings volg gewoonlik spoedig op die voorspelling.

Wanneer ' $n$ profeet aan ' $n$ instelling soos die kultus verbind word, gaan daar iets van sy boodskap verlore. Om agting vir 'n profeet in die verlede te hê is tog iets anders as om in die hede na sy boodskap te luister en dit te aanvaar (vgl. McKane, 1982:262). Profete word dikwels in die hede legitimerend gebruik ten opsigte van instellings in die tyd van die skrywer(s). Die wyse waarop profete in Kronieke geskilder word, kan dalk ook 'n reaksie wees teen die opkoms van die apokaliptiek in die tyd van die skrywer(s). Die ontwikkeling van apokaliptiek uit profesie was nie maar ' $n$ reglynige ontwikkeling nie (vgl. Petersen, 1977:55). Kronieke verwys na profete wat reeds dood is - en Auld (1983:67) stel dit baie skerp: 'n goeie profeet is altyd 'n dooie profeet

In die Persiese periode het die rol van profete al hoe kleiner geword en is profetisme deur apokaliptiek vervang (vgl. Carroll, 1979:204-205). In die geskiedenis soos deur Kronieke verhaal, speel konings, profete en Leviete 'n besondere rol en slegs die Leviete het oorgebly in 'n nuwe, veranderende wêreld. In die lig hiervan moet hulle dan beskou word as die wettige opvolgers van die leiers van die gemeenskap van voor die ballingskap. Die tempel sou die fokuspunt van die nuwe gemeenskap word (Petersen, 1977:56). Profete word in Kronieke gebruik om die rol van die tempel te beklemtoon.

Uit hierdie oorsig is dit duidelik dat die profete gesagvolle stemme uit die verlede geword het wat ' $n$ boodskap vir 'n nuwe tyd gehad het. Hulle verbinding met Leviete in die verlede beklemtoon die rol van die Leviete in die nuwe tyd. Van die ou leiers het slegs die profete oorgebly en hulle was geskik om die volk 'n nuwe toekoms in te lei.

Die bespreking toon aan dat die gesigshoek van die skrywer(s), 'n rol gespeel het in die wyse waarop die geskiedenis benader en beskryf is in 'n nuwe tyd met nuwe eise en met 'n nuwe samestelling van die gemeenskap. Die gevolg is nie bevooroordeelde geskiedenis nie, maar 'n geskiedenis wat ten nouste verweef is met die skrywer(s) se gesigshoek

\section{Kerkgeskiedenis en gesigshoek}

Die saak van die gesigshoek van die geskiedskrywer moet ook in kerkgeskiedenis in gedagte gehou word. Die gedagte van werklike objektiewe kerkgeskiedskrywing in positiwistiese sin, bly 'n onmoontlikheid, omdat 'n geskiedskrywer hom nooit ten volle kan losmaak van sy historiese konteks nie. Dit blyk duidelik uit die bespreking van die invloed van die skrywer(s) se gesigshoek op die wyse 
waarop profete in Kronieke aan die orde kom. Die geskiedskrywer moet egter steeds van sy eie staanplek bewus wees en raaksien hoe sy gesigshoek sy versameling en interpretasie van 'feite uit die verlede' beinvloed. Vir die doel van hierdie artikel kan met een voorbeeld die verband tussen gesigshoek en interpretasie in kerkgeskiedskrywing geïlustreer word.

In die werk van Gerdener (1930:6,7), waarin daar 'n verskeidenheid argivale materiaal opgeneem is, verskyn daar ' $n$ brief van ds. Dirk Postma aan die Kerkraad van Pietennaritzburg. Die 'feite' waaroor die brief handel, is dus maklik bekombaar en kontroleerbaar. Die brief is ongedateer, maar kom duidelik uit die tyd toe ds. Postma vanuit Nederland na die Transvaal onderweg was. Scholtz (1956:150) noem ook die brief 'n ongedateerde brief, terwyl Van der Vyver (1958:181, voetnoot 36) die brief op 27 September 1858 dateer. In dié brief bedank ds. Postma die kerkraad vir die goeie ontvangs wat hom daar te beurt geval het en wil hy inligting gee oor die doel van sy sending na Suid-Afrika. Sy opdrag verbind hy aan twee sake, naamlik die sendingopdrag, met verwysing na Matteus 28:19 en Markus 16:15, asook die toestand van die stamverwante en geloofsgenote in die Transvaal. Hy sê self dat laasgenoemde "verwierf in de eerste plaats boven alles de voorkeur" (Gerdener, 1930:6). Hierna gee hy in twee paragrawe 'n kort uiteensetting van die kerk waaruit hy kom. Daama verklaar hy iets oor sy siening van die kerk waanmee hy nou kontak gemaak het. Vir die verdere bespreking word die paragraaf volledig aangehaal (Gerdener, 1930:6):

Zoover wij bekend zijn met de Gereformeerde Kerk van Z. Afrika, beschouwen wij deze met ons homogeen, en het is ons innigst verlangen al wat wij hier doen, met haar in de beste overeenstemming te doen, alware het dan niet in diezelfde kerkelijke gemeenschap.

Hierna stel ds. Postma (Gerdener, 1930:7) dat hy alleen maar soek na die opbou en uitbreiding van die koninkryk van God in eg gereformeerde (Christelike) sin. Hy sê ook dat hy die gemeenskap van die broeders najaag en ook dat hy seker is dat sy adressante hom hierin sal bystaan.

Die brief kan dus maklik gelees word, maar die interpretasie is nie so eenvoudig nie. Een wyse waarop die brief geinterpreteer is, kom in die werk van dr. G.D. Scholtz (1956:150) na vore. Hy oordeel dat ds. Postma in hierdie brief in Natal die eerste keer te kenne gegee het dat hy 'n nuwe kerk wil stig, om sodoende die kerklike verdeeldheid in Nederland na Suid-Afrika oor te plant. Die motivering vir die interpretasie is die paragraaf uit ds. Postma se brief wat hierbo aangehaal is. Sy afleiding hieroor word soos volg saamgevat (Scholtz, 1956:150):

Vir ' $n$ vreemdeling was dit werklik onvanpas om 'n kerklike verdeeldheid waarvoor daar in sy vaderland rede bestaan het, te gaan oordra na ' $n$ land en ' $n$ volk waar sodanige redes nie bestaan het nie. 
Hy verwyt hiena sommige Nederlanders wat verdeeldheid gebring het op plekke waar daar eenheid bestaan het.

In sy biografie van ds. Postma, haal Van der Vyver (1958:183-184) ook hierdie paragraaf uit ds. Postma se brief aan. Hy verwys ook na Scholtz se interpretasie van die paragraaf, wys dit af en gee 'n ander interpretasie daarvan. Sy afwysing van Scholtz se interpretasie word op twee argumente gebou. In die eerste plek sê hy dat ds. Postma in dieselfde brief verklaar dat sy kerk en die Gereformeerde Kerk in Suid-Afrika, dit wil sê die N.G. Kerk, homogeen is. Skeuring van so 'n kerk is vir Van der Vyver nie te rym met die persoon en optrede van ds. Postma nie. Tweedens oordeel Van der Vyver dat daar geen getuienis is dat Postma se koms na Suid-Afrika kerkstigting tot doel gehad het nie (vir die volledige motivering, vgl. Van der Vyver, 1958:183).

Van der Vyver se eie interpretasie probeer om die verband van die brief in ag te neem. Die brief was gerig aan 'n kerkraad en Ring wat in kerklike gemeenskap met die Kaapse Sinode was, terwyl Postma op pad was na die Transvaal, wat sedert 1853 buite die kerklike gemeenskap van die Kaapse Sinode was. Hy was self op pad na die Transvaal en sou dus in daardie kerklike gemeenskap gaan werk (vgl. Van der Vyver, 1958:183-184). Hier is daar duidelik sprake van twee gesigshoeke. By Van der Vyver sal 'n mens uit die aard van die saak verwag dat hy die gewraakte uitspraak ten goede sal interpreteer.

Scholtz se interpretasie kan vergelyk word met sy hantering van die verbreking van die bande tussen die Kaapse Sinode en die kerk in die Transvaal na die koms van ds. Dirk van der Hoff (Scholtz, 1956:77-103). Op die ou end is sy slotsom dat ds. Van der Hoff die skuld moet kry. Sy opmerking waarna reeds verwys is, naamlik dat Hollanders verdeeldheid in Suid-Afrika gebring het, kan as iets van 'n apologetiese opmerking beskou word wat sy beoordeling van die optrede van ds. Van der Hoff en die gewraakte paragraaf in die brief van ds. Postma beïnvloed het. Die oorsaak vir kerklike verdeeldheid in Suid-Afrika is dan nie soseer te wyte aan probleme wat daar dalk in die N.G. Kerk kon gewees het nie, maar aan buitelanders wat 'n buitelandse verdeeldheid na Suid-Afrika oorgedra het. Elkeen kan self oor die verskillende interpretasies oordeel, maar die gesigshoek van die kerkgeskiedskrywer is daaruit duidelik. Hoe belangrik dit is dat die hoek van die skrywer raakgesien moet word wanneer daar later van sy werk gebruik gemaak word, blyk uit Van der Watt (1973:73) se verwysing na hierdie paragraaf uit Postma se brief. Hy sluit in sy interpretasie ten volle by Scholtz aan, sonder enige vermelding van die afwysing van daardie interpretasie en die ander interpretasie deur Van der Vyver voorgestel. In sy verdere bespreking van die faktore wat aanleiding gegee het tot die afskeiding van die Gereforneerde Kerke, speel die ingesteldheid tot skeuring ook nie ' $n$ rol nie, sodat die funksionaliteit van die 
betrokke punt nêrens duidelik word nie, behalwe as ' $n$ apologetiese stellinginname.

\section{Slot}

Die beskrywing van geskiedenis - of dit nou gewone geskiedenis, kerkgeskiedenis of Bybelse geskiedenis is - kan dus nooit los gemaak word van die hoek waaruit die geskiedskrywer sy materiaal benader nie. Elkeen wat hom besig hou met geskiedskrywing moet dit besef, ook wat sy eie werk betref. Verskillende gesigshoeke kan mekaar meennale aanvul om so die werklikheid uit verskillende hoeke te belig. Wanneer 'n historiese werk bestudeer word, moet daar ook gevra word na die tyd en gesigshoek van die skrywer, om so ook iets te probeer verstaan van die boodskap wat hy vir sy tyd gehad het. Vir die verstaan van die boodskap van Kronieke is dit uiters belangrik on steeds die gesighoek van die skrywer binne die Persiese tyd in gedagte te hou: sy gesigshoek wat deur sy belewing van sy eie tydsgewrig 'gekleur' word, laat hom ander sake in die geskiedenis beklemtoon as wat die geval in Samuel en Konings is. Kronieke bevat nie 'objektiewe geskiedenis' nie, maar geskiedenis wat doelbewus 'n nuwe boodskap in 'n nuwe tyd wil laat hoor en wat sodoende 'n nuwe pad vir die toekoms wil aandui.

Objektiewe geskiedskrywing in positiwistiese sin is onbereikbaar, daarom moet die historikus steeds sy eie beperkinge besef en beskeie bly in sy rekonstruksie van die verlede. Die historikus se interpretasie van die geskiedenis kan nooit presies gelyk wees aan die geskiedenis 'soos dit regtig gebeur het' nie - net soos wat die eksegeet se feilbare interpretasie van die Bybel nooit gelykgestel kan word aan die Bybel nie. In kerkgeskiedskrywing moet die kerkhistorikus steeds die beperkinge wat sy eie gesigshoek veroorsaak, raaksien. Daarom is dit ook telkens nodig on weer die geskiedenis van enige kerk in oenskou te neem; ook die geskiedenis van die Gereformeerde Kerke in Suid-Afrika moet telkens weer bestudeer word. Die interpretasies van die geskiedenis in die verlede moet steeds weer beoordeel word, om so ook die gesigshoek van die skrywers daarvan onder oë te neem. In 'n tyd van politicke verandering sal daar met groter aandag gelet word op die invloed van politieke omstandighede op die geskiedenis van die Kerke - en ook op die invloed van sulke omstandighede op die beskrywing van die geskiedenis. Die geskiedenis van 'n kerk kan nooit klaar geskryf wees nie en juis daarom is die beskrywing van die geskiedenis van die Gereformeerde Kerke juis nou weer baie nodig.

\section{Bibliografie}

ACKROYD, PR 1973. I \& II Chronicles, Ezra, Nehemiah London: SCM (Torch Bible Paperbacks) 
AULD, A.G. 1983 Prophets through the Looking Glass. Between Writings and Moses. Journal for the Study of the Old Testament, 27:3-23.

BEGG, C T 1986. The Non-Mention of Ezekiel in the Deuteronomistic History, the Book of Jeremiah and the Chronistic History. (In Lust, J ed. Ezekiel and His Book. Textual and Literary Criticism and Their Interrelation [Bibliotheca Ephemeridum Theologicarum Lovaniensum LXXIV.] Leuven : Leuven University Press \& Uitgeverij Peeters. p 340343.)

BEGG, C. T 1988a. The Chronicler's Non-Mention of Elisha Biblischen Notizen, 45:7-1 1

BEGG, C.T. 1988b The Classical Prophets in the Chronistic History Biblische Zeitschrift, 32:100-107

BLENKINSOPP, J. 1984. A History of Prophecy in Israel. London : SPCK

BROWN, E. 1988. Die beredenering van die kerkhistoriografie in ons eie tyd Studia Historiae Ecclesiasticae, 14:27-49

CARROLL, R P. 1979 When Prophecy Failed Reactions and Responses to Failure in Old Testament Prophetic Traditions. London : SCM.

CARROLL, R P 1989. Prophecy and Society (In Clements, RE ed. The World of Ancient Israel Sociological, Anthropological and Political Perspectives Cambridge: University Press. p. 203-225.)

DE VRIES, S.J. 1989. 1 and 2 Chronicles. Grand Rapids, Michigan : Eerdmans. (The Forms of the Old Testament Literature.)

DEIST, F.E. 1986 Verteltekste (In Deist, FE. \& Vorster, W S reds. Woorde wat ver kom Kaapstad: Tafelberg p. 69-102. (Die literatuur van die Ou Testament 1))

DILLARD, R.B 1987 2 Chronicles Waco, Texas: Word Books (Word Biblical Commentary 15 )

EATON, J.H 1984 Music's Place in Worship: A Contribution from the Psalms Ondtestamentische Studien, XXIII 85-107

ESKENAZI, T C. 1986 The Chronicler and the Composition of 1 Esdras' ('atholic Biblical Quarterly, 48:39-61.

GERDENER, GBA 1930. Boustowwe vir die geskiedenis van die Nederduits-Gereformeerde Kerk in die Transgariep. Kaapstad : Nasionale Pers

HALPERN, B 1988 The First Historians. The Hebrew Bible and History San Fransisco Harper \& Row

HANSON, P D 1975. The Dawn of Apocalyptic. Philadelphia : Fortress

LANDMAN, C 1988 Presuppositions to the Writing of Church History in South Africa Studia Historiae Ecclesiasticae, 14:68-77

LICHT, J 1984 Biblical Historicism (In Tadmor, H \& Weinfeld, M eds. History, Historiography and Interpretation Studies in Biblical and Cuneiform Literatures Jerusalem/ Leiden : Magnes/Brill, p. 107-120.)

LONG, B O. 1977. Prophetic Authority as Social Reality. (I/I Coats, G W. \& Long. B O eds Canon and Authority. Essays in Old Testament Religion and Theology. Philadelphia : Fortress. p 3-20)

McCANE, W. 1982 Prophet and Institution Zeitschrift fiur die Alttestamentiche Wissenschaft, 94:251-266

McKENZIE, SL 1985. The Chronicler's Use of the Deuteronomistic History Atlanta, Georgia : Scholars Press (Harvard Semitic Monographs 33)

MICHEEL, R 1983 Die Seher- und Prophetenuberlieferungen in der Chronik Frankfurt am Main : Peter Lang. (Beitrage zur biblischen Exegese und Theologie 18)

MILLER, JM \& HAYES, J.H 1986 A History of Ancient Israel and Juda Philadelphia Westminster Press 
NEWSOME, J D. 1975 Towards a New Understanding of the Chronicler and His Purpose Journal of Biblical Literature, 94 201-217.

PETERSEN, D L 1977. Late Israelite Prophecy: Studies in Deuteroprophetic Literature and in Chronicles Missoula, Montana Scholars Press (Society of Biblical Literature Monograph Series 23.)

POPPER, K.R 1962. The Open Society and Its Enemies. II. The High Tide of Prophecy: Hegel, Marx and the Aftermath London: Routledge \& Kegan Paul.

RIENSTRA, M H. 1984 History, Objectivity, and the Christian Scholar. (In McIntyre, C.T. \& Wells, R A eds. History and Historical Understanding. Grand Rapids, Michigan : Eerdmans p 69-82.)

SCHOLTZ, G.D 1956. Die geskiedenis van die Nederduitse Hervormde of Gereformeerde Kerk van Suid-Afrika deel 1 1842-1885. Kaapstad : N.G Kerkuitgewers

SMITH, M 1971. Palestinian Parties and Politics that Shaped the Old Testament. New York. Columbia University Press

VAN DEN BERGH, G.N 1977. Die historikus as skepper van die geskiedenis Potchefstroom PU vir $\mathrm{CHO}$ (Wetenskaplike bydraes van die PU vir CHO. Reeks $\mathrm{H}$ : inougurele redes nr. 30.)

VAN DER VYVER, G C P 1958 Professor Dirk Postma 1818-1890. Potchefstroom : Pro Rege

VAN DER WATT, P B 1973 Die Loedolff-saak en die Nederduitse Gereformeerde Kerk 1862-1962 'n Kerkhistories-kerkregtelike studie Kaapstad: Tafelberg (Raad vir Geesteswetenskaplike Navorsing publikasiereeksnommer 39.)

VAN DER WATT, P B 1975 Gedagtes rondom 'n komtemporêre kerkgeskiedenis - met besondere verwysing na die Ned Geref Kerk Pretoria: Universiteit van Pretoria (Publikasies van die Universiteit van Pretoria Nuwe reeks nr 92)

VAN JAARSVELD, F.A 1984 Omstrede Suid-Afrikaanse verlede Geskiedenis-ideologie en die historiese skuldvraagstuk Johannesburg Lex Patria

VAN JAARSVELD, F.A 1989. Historical Consciousness and the Reinterpretation of History University of Zululand (Publication series of the University of Zululand B76.)

WILSON, R R 1980 Prophecy and Society in Ancient Israel Philadelphia : Fortress. 
